\title{
The Effect of Cyclic Heat Stress Applied to Different Broiler Chicken Brooding Stages on Animal Performance and Carcass Yield
}

\section{Euthor(s)}

Marchini CFP' (iD https://orcid.org/0000-0002-9705-072X Fernandes EA" (iD https://orcid.org/0000-0002-5806-3763 Nascimento MRBM"

(D) https://orcid.org/0000-0003-4324-5262 Araújo EG"I (iD https://orcid.org/0000-0003-0890-017X

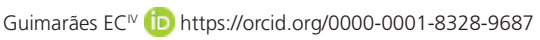
Bueno JPR" (iD https://orcid.org/0000-0001-6177-3187 Fagundes NS" (D) https://orcid.org/0000-0001-6281-0779 Café MB"IID https://orcid.org/0000-0002-1478-8009

UNIFRAN - Medicina Veterinária - Rua Rio Grande do Sul, 1795 - Vila Aparecida, Franca, Brasil 14401324.

Universidade Federal de Uberlândia - Rua Ceará s/n; Bloco 2D; Sala 36, Uberlândia, Minas Gerais, Brazil - 38402-018.

III Universidade Federal de Goiás - Escola de Veterinaria e Zootecnia Ringgold standard institution - Escola de Veterinária e Zootecnia Av. Esperança S/N - Campus Universitário Samambaia, Goiânia, Goiás, Brasil - 74690-900.

Universidade Federal de Uberlândia - FAMEV Rua Ceará, Bloco 2d, Uberlândia, MG, Brazil 38499902.

\section{-Mail Address}

Corresponding author e-mail address Cristiane Ferreira Prazeres Marchini

UNIFRAN - Medicina Veterinária - Rua Rio Grande do Sul, 1795 - Vila Aparecida,

Franca, São Paulo, Brasil - 14401324.

Phone: +5516992199180

Email: cfprazeres@gmail.com

\section{-Keywords}

Air humidity, carcass traits, environmental temperature, poultry, thermal stress.

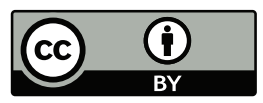

Submitted: 31/October/2017 Approved: 28/January/2018

\section{ABSTRACT}

The objective of this study was to evaluate the performance and carcass yield of broilers submitted to heat stress during different rearing stages. A total of 840 one-day-old CobbAvian48 ${ }^{\mathrm{TM}}$ male broilers were housed in an experimental house equipped with conventional ventilation system and foggers. Birds were distributed according to a completely randomized design into four treatments, with six replicates of 35 birds each. The treatments consisted of: T1 (control) - birds reared under natural temperature and relative humidity conditions from 1 to 42 days of age; T2 - birds submitted to heat stress (HS) from 16 to 21 days of age; T3 - birds submitted to HS from 22 to 42 days of age; and T4 - birds submitted to HS from 16 to 42 days of age. Birds were submitted to heat stress daily for one hour (12:00-13:00h). On day 42 , performance data were determined. Six birds per replicate were selected and sacrificed to obtain carcass, parts, and giblet weights and yields. Performance parameters were not influenced by the treatments. Broilers submitted to 1-h cyclic heat between 16 and 42 days of age presented lower deboned breast weight compared with those maintained in natural temperature and relative humidity conditions. It was concluded that the performance of broilers submitted to short cyclic heat periods is not impaired.

\section{INTRODUCTION}

Factors such as temperature and air humidity induce changes in bird homeostasis (Lin et al., 1996; Yahav et al., 2004). Birds above the thermoneutral zone increase heat dissipation to maintain thermal balance. Broiler chickens' growth, development (Mazzi et al., 2002) and performance (Borges et al., 2003) are impaired under these thermal discomfort conditions, fact that leads to economic losses in the breeding activity.

The exposure to high ambient temperatures is acknowledged for having negative effects on carcass (Oliveira et al., 2006a; Oliveira et al., 2006b) and noble cut yields (Oliveira et al., 2006b). These losses take place because elevated temperatures change energy retention, protein and fat deposition in the carcass, as well as viscera growth (Baldwin et al., 1980). Reduced feed intake (by $12.4 \%$ and $28 \%$ ) and decreased weight gain (by $18 \%$ and $44 \%$ ) are among the adverse effects from heat stress recorded for birds bred at $30^{\circ} \mathrm{C}$ and $35^{\circ} \mathrm{C}$, respectively (AlFataftah \& Abu-Dieyeh, 2007).

Different physiological responses may emerge under heat stress depending on its intensity, severity and duration (Gonzalez-Esquerra \& Leeson, 2006). The exposure to heat stress for 50 minutes is sufficient to trigger thermoregulatory response changes in broilers such as hyperthermia (Yanagi Jr. et al., 2001). Silva et al. (2007) reported increased body temperature and respiratory rate in 42-day-old broiler 
Marchini CFP, Fernandes EA, Nascimento MRBM, Araújo EG, Guimarães EC, Bueno JPR, Fagundes NS, Café MB
The Effect of Cyclic Heat Stress Applied to Different Broiler Chicken Brooding Stages on Animal Performance and Carcass Yield chickens subjected to 30-minute exposure to high temperatures and relative humidity.

Most studies on the effects of heat stress on broiler performance were conducted in climatic chambers with high ambient temperatures (Oliveira Neto et al., 2000; Furlan et al., 2001; Rosa et al., 2007) applied are acutely or chronically (Al-Fataftah \& Abu-Dieyeh, 2007; Quinteiro Filho et al., 2012). However, ambient temperature and air humidity under natural conditions are not constant and may reach high annual values in Brazil, because it is located the tropical zone of the Southern hemisphere. In addition, diurnal variations in air temperature are recorded: it rapidly increases after 08:00, peaks between 12:00 and 15:00, after which it decreases and stabilizes at 21:00 (Silva \& Costa, 2000).

Therefore, it is worth investigating the effects from elevated temperatures recorded in conventional poultry house on poultry performance, since studies about heat stress applied to different broiler chicken breeding stages remain scarce.

Therefore, the aim of the current study was to investigate the effects from cyclic heat stress applied for one hour per day during different age periods on the live performance and on carcass, valuable parts and giblet weights and yields of broiler chickens.

\section{MATERIALS AND METHODS}

All the procedures adopted in the present study were approved by the Ethics Committee on Animal Use of Federal University of Uberlândia (UFU), Brazil, according to Protocol CEUAJUFU 024/10

The experiment was conducted in the poultry experimentation sector of the afore mentioned university. The poultry house was made of a masonry and metal structure, fiber cement roof, concrete floor covered with wood-shavings litter, open sides covered with plastic canvas curtains, and equipped with foggers and ventilation fans. The house was divided in 24 pens, each equipped with two drinkers each (one automatic nipple drinker and one bell drinker), one tube feeder. An infrared brooder was provided to each four pens.

In this experiment, 840 one-day-old male CobbAvian $48^{\mathrm{TM}}$ broiler chickens were evaluated according to a completely randomized design, with four treatments with six replicates (pens) with 35 birds each at a density of $10.9 \mathrm{birds} / \mathrm{m}^{2}$. The treatments consisted of four thermal environments: control (natural temperature and humidity conditions) and heat stress from 12:00 to $13: 00$ submitted during the periods of 16 to 21,22 to 42 and 16 to 42 days of age.
From one to 14 days of age, all broilers were kept under thermoneutral conditions, and were submitted to the thermal treatments 16 to 42 days of age.

In order to obtain the heat stress environment, double plastic curtains (black and white double-sided canvas) were placed across the poultry house in order to establish four environmental chambers. The fans were kept on during the heat stress period to ensure adequate ventilation.

House temperature (ET) and relative air humidity $(\mathrm{RH})$ were daily monitored 10:00 and 17:00 h, with the aid of a psychrometer Incoterm ${ }^{\circledR}$ (model 5195.03.0.00, Incoterm, Porto Alegre, Brazil) placed in each chamber at $30 \mathrm{~cm}$ height from the litter.

The chambers were preheated for 10 minutes before the heat exposure period using infrared brooders in order to achieve reach the heat stress temperatures, i.e., temperatures higher than $36^{\circ} \mathrm{C}$. During the heat stress period, chamber environmentaltemperature (ET) and relative humidity $(\mathrm{RH})$ were monitored every 10 minutes using a Portable Digital Thermal Stress Meter (model TGD-200, Instrutherm ${ }^{\circledR}$, São Paulo, Brazil). Based on the obtained data in each environmental chamber, ET and RH means and standard deviations were calculated for each experimental period (1621, 22-42 and 16-42 days) and compared with the maximum (ETs handbook) and minimum (ETi handbook) thermal comfort temperatures as function of $\mathrm{RH}$ recommended in the genetic strain handbook (Cobb, 2008).

The plastic curtains were opened at the end of the heat stress period to allow ET and $\mathrm{RH}$ to return to the natural conditions within 10 minutes. Ventilation fans and foggers were activated to provide thermal comfort conditions when needed.

All the birds received water ad libitum and were fed diets formulated according to nutritional levels recommended by Rostagno et al. (2005), and based on sorghum, soybean meal, soybean soap stock, dicalcium phosphate, limestone, sodium chloride, vitamin and mineral supplements, and commercial additives. Diets were fed according to 4-phase feeding program as follows: pre-starter (1 to 7 days), starter ( 8 to 21 days), grower (22 to 33 days) and finisher (34 to 42 days). A lighting light regime of $20 \mathrm{~h}$ of light and 2 hours of dark (22L:2D) was applied from 1 to 7 days, 20L:4D from 8 to 21 days, and 22L:20D from 22 to 42 days of age, according to the Cobb handbook (2008). Water and feed were not supplied during the heat stress period.

All birds were weighed on pen basis (35 birds/pen) on a digital scale at 1 and 42 days of age to determine 
Marchini CFP, Fernandes EA, Nascimento MRBM, Araújo EG, Guimarães EC, Bueno JPR, Fagundes NS, Café MB
The Effect of Cyclic Heat Stress Applied to Different Broiler Chicken Brooding Stages on Animal Performance and Carcass Yield average initial and final body weight, total weight gain, average daily gain.

Feed intake was determined as feed offer minus feed residues and the feeders, and feed conversion ratio as feed intake relative to weight gain, both corrected for mortality, according to Sakomura \& Rostagno (2016). Livability was determined as the percentage of live birds at the end of the experimental period relative to the initial number of birds. Production efficiency index was calculated according to the following equation:

$P E I=[(D W G \times L) \div(F C R)] \times 100$

where: $\mathrm{PEI}=$ productive efficiency index; $\mathrm{DWG}=$ daily weight gain $(\mathrm{kg}) ; L=$ livability $(\%)$; and $F C R=$ feed conversion ratio.

At 42 days of age, all birds in each pen were weighed, and their final average body weight was determined. Next, one bird which body weight was closest to the pen's average BW $( \pm 5 \%)$ was selected per pen (6/treatment), submitted to 8 -h feed fasting and 4-h fasting, and sacrificed by cervical dislocation. Carcasses were plucked, eviscerated, and absolute (g) and relative (\%) carcass weight (with no feet, head and neck) were calculated relative to final BW. The absolute (g) and relative (\%) weights of valuable parts (breast with bone, deboned breast, drumstick and thigh, drumette and wingand breast fillet) and of giblets (heart, liver and gizzard) were determined.

Performance and carcass yield data presented normal distribution, according to Shapiro-Wilk test, and were subjected to analysis of variance. Means were compared by Tukey's test. Final body weight and weight gain were subjected to the KolmogorovSmirnov test because the data did not present normal distribution as per the Shapiro-Wilk test. Statistical significance was considered at 5\% probability level. Statistical analyses were performed using the software SISVAR (Ferreira, 2000).

\section{RESULTS AND DISCUSSION}

Figure 1 shows the weekly means and standard deviations of dry-bulb temperatures $\left(\mathrm{ET} ;{ }^{\circ} \mathrm{C}\right)$ and relative humidity ( $\mathrm{RH} ; \%)$ measured at 10:00 and 17:00 in the four experimental chambers and the lowest (ETi handbook) and highest (ET s handbook) thermal comfort temperatures recommended by the handbook of the genetic line for each rearing age (days).

The environmental temperature (ET) means recorded during the heat-stress period on days 16-21, 22-28, 29-35 and 36-42 were, respectively, $25.4{ }^{\circ} \mathrm{C}$, $27.8^{\circ} \mathrm{C}, 26.9^{\circ} \mathrm{C}$ and $24.9{ }^{\circ} \mathrm{C}$ for the control group, $26.7^{\circ} \mathrm{C}, 26.1^{\circ} \mathrm{C}, 26.0^{\circ} \mathrm{C}$ and $24.3^{\circ} \mathrm{C}$ for the group submitted to heat stress between 16 and 21 days, 25.3 ${ }^{\circ} \mathrm{C}, 24.9{ }^{\circ} \mathrm{C}, 26.5^{\circ} \mathrm{C}$ and $24.4{ }^{\circ} \mathrm{C}$ for those submitted heat stress between 22 and 42 days and $25.0^{\circ} \mathrm{C}, 26.5$ ${ }^{\circ} \mathrm{C}, 26.6{ }^{\circ} \mathrm{C}$ and $22.5^{\circ} \mathrm{C}$ for those submitted to heat stress between 16 and 42 days of age. These means did not differ from the handbook recommendations for male CobbAvian48 ${ }^{\mathrm{TM}}$ broilers.

Relative humidity (RU) averages recorded during the heat stress periods at the ages of 16-21, 22-28, 2935 and 36-42 days were, respectively, 61.6\%, 54.9\%, $56.8 \%$ and $59.3 \%$ for the control group, $61.6 \%$, $58.9 \%, 58.7 \%$ and $66.0 \%$ for the group submitted to heat stress between 16 and 21 days, 59.9\%, 57.7\%, $53.8 \%$ and $59.4 \%$ for those submitted heat stress between 22 and 42 days and $75.6 \%, 65.0 \%, 64.6 \%$ and $75.5 \%$ for those under heat stress between 16 and 42 days of age.

These results shows that male CobbAvian48 ${ }^{\text {TM }}$ broiler chickens were kept in thermoneutral conditions from 1 p.m to 12 p.m. during the experimental period and that the RU were similar in all groups.

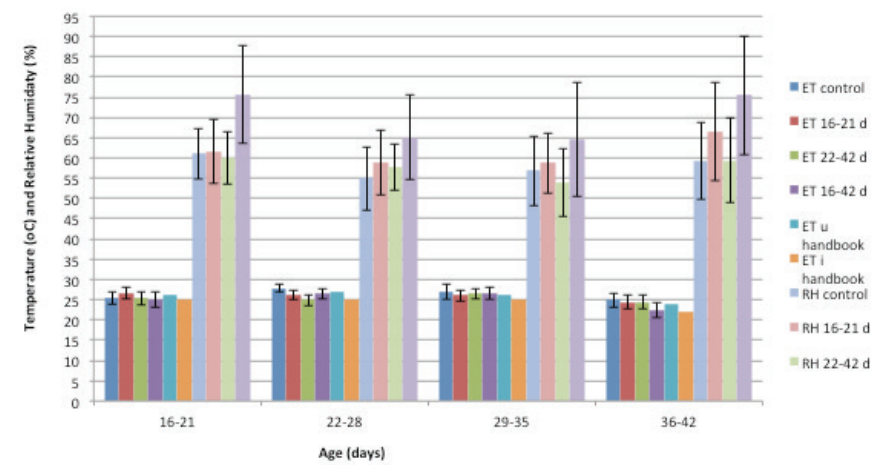

Figure 1 - Weekly environmental temperature and relative humidity measured under natural conditions.

The means of ET recorded during the heat stress period at 16-21, 22-28, 29-35 and 36-42 days were, respectively, $30.0^{\circ} \mathrm{C}, 27.2^{\circ} \mathrm{C}, 26.1^{\circ} \mathrm{C}$ and $25.4^{\circ} \mathrm{C}$ for the control group, $35.5^{\circ} \mathrm{C}, 28.9^{\circ} \mathrm{C}, 25.8^{\circ} \mathrm{C}$ and 24.1 ${ }^{\circ} \mathrm{C}$ for the group submitted to heat stress between 16 and 21 days, $30.9{ }^{\circ} \mathrm{C}, 35.4{ }^{\circ} \mathrm{C}, 36.5^{\circ} \mathrm{C}$ and $36.2^{\circ} \mathrm{C}$ for those submitted heat stress between 22 and 42 days and $35.4{ }^{\circ} \mathrm{C}, 35.9{ }^{\circ} \mathrm{C}, 36.8^{\circ} \mathrm{C}$ and $36.8^{\circ} \mathrm{C}$ for those submitted to heat stress between 16 and 42 days of age. These means shows that broilers were submitted to ET above the thermoneutral zone during the heat stress period, from 12:00 to 13:00.

Figure 2 shows the weekly means and standard deviations of dry-bulb temperatures $\left(\mathrm{ET} ;{ }^{\circ} \mathrm{C}\right.$ ) and relative humidity ( $\mathrm{RH} ; \%)$ measured during the 1-h heat exposure period in the four experimental chambers and the lowest (ETi handbook) and highest (ET s handbook) 
Marchini CFP, Fernandes EA, Nascimento MRBM, Araújo EG, Guimarães EC, Bueno JPR,

Fagundes NS, Café MB
The Effect of Cyclic Heat Stress Applied to Different Broiler Chicken Brooding Stages on Animal Performance and Carcass Yield thermal comfort temperatures recommended by the handbook of the genetic line for each rearing age (days).

Relative humidity average recorded during the heat stress period (12:00 to 13:00) at the ages of 16$21,22-28,29-35$ and 36-42 days were, respectively, $42.4 \%, 50.4 \%, 53.2 \%$ and $46.6 \%$ for the control group, $35.1 \%, 50.9 \%, 57.6 \%$ and $56.4 \%$ for the group submitted to heat stress between 16 and 21 days, $31.0 \%, 46.0 \%, 47.4 \%$ and $39.8 \%$ for those submitted heat stress between 22 and 42 days and $36.5 \%, 43.6 \%, 45.6 \%$ and $46.2 \%$ for those under heat stress between 16 and 42 days of age.

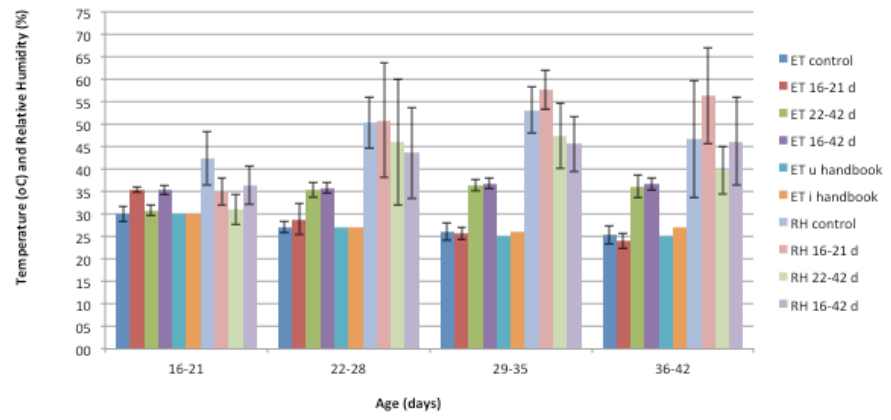

Figure $\mathbf{2}$ - Weekly environmental temperature and relative humidity measured during the heat exposure period.

The ET temperature differences were recorded between the heat-stress period (from 12:00 pm to 01:00 pm) and the period when birds were kept under natural temperature and humidity conditions (from 01:00 pm to 12:00 am in the following day) was $10.13^{\circ} \mathrm{C}$, on average (Figure 2). According to Donald (1997), birds are able to withstand higher daytime temperatures when the temperature difference between the day and night periods is at least $10{ }^{\circ} \mathrm{C}$, allowing the dissipation of the body heat accumulated during the day. However, when the temperature does not sufficiently decrease during the night, birds are not able to dissipate the heat accumulated during the day, which may negatively may affect their performance and increase their mortality (Lara \& Baião, 2005).

\section{Performance parameters}

The initial average body weight at the beginning of the experiment (16-d-old) were determined as 464.0 $\pm 9 \mathrm{~g}$ for the control group, and $467.7 \pm 9 \mathrm{~g}, 453.0$ $\pm 9 \mathrm{~g}$ and $453.0 \pm 9 \mathrm{~g}$ for groups subjected to heat stress between 16-21, 22-42, and 16-42 days of age, respectively.

There was no effect of the treatments ( $p>0.05)$ on the evaluated performance parameters male CobbAvian48 ${ }^{\mathrm{TM}}$ (Table 1). This result may be partially explained by the fact that, after the heat stress period, natural temperature and humidity conditions were resumed with the activation of fans and foggers to provide a thermally comfortable environment. In addition, during the evening and throughout the night, environmental conditions were within comfortable limits, favoring feed intake. The ability of birds to dissipate heat during the coolest period of the day is one of the main differences between constantly high temperatures and those cyclic hot temperatures (Leone et al., 2001; Ribeiro et al., 2001), as broilers kept under constant heat stress are unable to reestablish homeothermy, which impairs their performance (Dionello et al., 2002; Abu-Dieyeh 2006; Oliveira et al., 2006a). One-hour heat exposure is enough to cause physiological changes, such as increase in body temperature and respiratory rate (Yanagi et al., 2001; Silva et al., 2007); however, the high cyclic temperatures to which broilers were subjected in the present study were not severe and prolonged enough to negatively impact their performance. Moreover, the adopted lighting regime enabled birds to have access to food and water during night, which may have allowed them recover from the effects of the one-

Table 1 - Average performance results of 42-day-old male reared under natural environmental conditions or exposed to 1-h cyclic heat stress for different age periods.

\begin{tabular}{|c|c|c|c|c|c|c|}
\hline & \multicolumn{4}{|c|}{ Heat exposure ages (days) } & \multirow{2}{*}{ CV $(\%)$} & \multirow{2}{*}{$P$ value } \\
\hline & Control & 16 to 21 & 22 to 42 & 16 to 42 & & \\
\hline Final BW (g) & 2.829 & 2.867 & 2.806 & 2.861 & 2.64 & 0.479 \\
\hline WG (g) & 2.781 & 2.820 & 2.759 & 2.812 & 2.69 & 0.481 \\
\hline ADWG(g) & 66.22 & 67.13 & 65.69 & 66.96 & 2.69 & 0.484 \\
\hline $\mathrm{FI}(\mathrm{g})$ & 4.725 & 4.706 & 4.713 & 4.687 & 2.82 & 0.965 \\
\hline ADFI (g) & 112.5 & 112.0 & 112.2 & 111.6 & 2.82 & 0.965 \\
\hline FCR & 1.69 & 1.66 & 1.71 & 1.66 & 2.15 & 0.134 \\
\hline Livability (\%) & 98.57 & 97.69 & 96.72 & 98.09 & 2.09 & 0.468 \\
\hline PEl* & 390.7 & 399.6 & 378.1 & 401.3 & 3.74 & 0.050 \\
\hline
\end{tabular}

Different lowercase letters on the lines differ from each other, according to the Tukey test $(p<0.05)$.

WG: weight gain; ADWG: average daily weight gain; FI: feed intake; ADFI: average daily feed intake; FCR: feed conversion ratio; PEl: production efficiency index 
Marchini CFP, Fernandes EA, Nascimento MRBM, Araújo EG, Guimarães EC, Bueno JPR, Fagundes NS, Café MB
The Effect of Cyclic Heat Stress Applied to Different Broiler Chicken Brooding Stages on Animal Performance and Carcass Yield hour heat stress to which they were subjected during the day. Therefore, the final body weight, weight gain, average daily weight gain, feed intake, average daily feed intake, feed conversion ratio, livability and production efficiency index of the heat-stress broilers were statistically similar to those recorded in broilers maintained under constant natural temperature and humidity conditions.

The results of the current experiment corroborate with those reported by Akşit et al. (2006), who did not find any effect of cyclic heat stress $\left(28^{\circ} \mathrm{C}\right.$ from $10: 00$ to $17: 00$ and $22^{\circ} \mathrm{C}$ from $17: 00$ to $10: 00$ between 3 and 7 weeks of age) on the broiler body weight and feed intake.

However, the weight gain, feed conversion ratio and mortality results obtained in the present study differed from those recorded by Quinteiro Filho et al. (2010) and Mello et al. (2015), who reported that these parameters were impaired in broilers subjected to cyclic heat stress ( $36{ }^{\circ} \mathrm{C}, 10$ hours a day, at $35-42$ days of age) or to continuous heat stress $\left(32^{\circ} \mathrm{C} \pm 0.5^{\circ} \mathrm{C}\right.$, for 72 hours at 4 and 6weeks of age), respectively. Salabi et al. (2011), differently from the present results, reported lower feed intake and weight gain, as well as worse feed conversion ratio in broiler chickens subjected to cyclic heat stress $\left(37^{\circ} \mathrm{C}\right.$ for six hours at $45 \%$ relative humidity) from 3 to the 7 weeks of age. These differences may be attributed to the fact that the aforementioned authors applied longer heat stress periods and housed birds in climatic chambers, whereas in the present experiment, birds were exposed only to $1-h$ heat stress and were housed in a conventional shed.

According to Hurwitz et al. (1980), high mortality rates are recorded when the ambient temperature exceeds $38^{\circ} \mathrm{C}$. The highest mean temperature recorded during heat stress in the current experiment was 36.8 ${ }^{\circ} \mathrm{C}$ applied for one hour after day 28 in birds exposed to heat stress from 16 to 42 days of age (Figure 2). Altan et al. (2000) reported that the livability of fastgrowing broilers subjected to $38{ }^{\circ} \mathrm{C}$ for 24 hours between 1 and 35 days of age was not compromised, which temperature is more challenging than those used in the current experiment.

The differences in environmental conditions, bird age during heat stress exposure, and individual variations among studies may explain the variable responses reported in literature. In addition, most studies on the effects of heat stress on broiler performance were conducted in climatic chambers, which temperature and relative humidity conditions are different from those under natural rearing conditions recorded in open-sided poultry houses, according to May \& Lott (2000).

Cyclic heat stress did not influence $(p>0.05)$ the evaluated carcass, valuable parts, and giblets yields, except for absolute boneless breast weight $(p<0.05)$ of the birds exposed for the longest period, i.e., from 16 to 42 days of age, which was $16.14 \%$ lighter compared with that of the control birds (Table 2). This result may be explained by changes in protein metabolism caused by heat stress, which reduces protein synthesis and increases breast muscle fiber catabolism rate (Zhang et al., 2012). It should be emphasized that breast weight reduction is undesirable due to the high economic value of this part. According to Fernandes et al. (2002), chicken breast is an important part of the consumer market, since it results in higher economic compensation in comparison with other carcassparts. Average absolute boneless breast weights, however, were not different among broilers submitted to cyclic heat stress.

The current study demonstrated that the exposure of broilers to cyclic heat stress differently influenced their muscles. Heat stress did not influence drumstick and thigh weight compared with bone-in and deboned breast weights, indicating the possible prioritization of protein deposition in the drumstick and thigh muscles relative to the breast muscle. This may be explained by the characteristics of the muscle fibers of each muscle group. Broiler breast muscle (Pectoralis major) consists of type-llb fibers (fast contraction myoglobinpoor glycolytic fibers) and require low blood supply and oxygen. These fibers easily fatigable that accumulate lactic acid and have low metabolic and oxygen exchange rates (Banks, 1992; Ono et al., 1993; Rosser et al., 1996). On the other hand, type-l fibers are predominant in the drumstick and thigh muscles. Type-Ifibers are myoglobin-rich, oxidative, present slow contraction and require high blood and oxygen supply (Ono et al., 1993; Rosser et al., 1996).

Heatstress may also exert different effects on different muscle fiber types due to action of corticosterone, which levels are higher when animals are maintained at elevated temperatures, and its catabolic effects on glycolytic fibers are more pronounced than on oxidative fibers in mammals (Silva, 2002). In addition, muscle growth mainly depends on the hypertrophy of glycolytic fibers (Sartori et al., 2003), which are predominant in the breast of broiler chickens (Rosser et al., 1996). Therefore, the results suggest that the effect of heat stress on the carcass muscles of broilers may vary according to the predominant type of muscle 
Marchini CFP, Fernandes EA, Nascimento MRBM, Araújo EG, Guimarães EC, Bueno JPR,

Fagundes NS, Café MB
The Effect of Cyclic Heat Stress Applied to Different Broiler Chicken Brooding Stages on Animal Performance and Carcass Yield

Table 2 - Absolute weights and yields of the carcass, valuable parts, and giblets of 42-day-old male CobbAvian48TM broilers reared under natural temperature and humidity conditions (control) or submitted to 1-h cyclic heat stress for different age periods.

\begin{tabular}{|c|c|c|c|c|c|c|}
\hline & \multicolumn{4}{|c|}{ Heat exposure age (days) } & \multirow{2}{*}{$C V(\%)$} & \multirow{2}{*}{$p$ value } \\
\hline & Control & 16 to 21 & 22 to 42 & 16 to 42 & & \\
\hline \multicolumn{7}{|c|}{ Absolute weights (g) } \\
\hline LW & 2.874 & 2.780 & 2.779 & 2.726 & 3.96 & 0.170 \\
\hline $\mathrm{C}-\mathrm{FHN}$ & 2.053 & 1.986 & 2.003 & 1.911 & 4.30 & 0.065 \\
\hline Breast with bone & 740.0 & 733.0 & 755.0 & 697.0 & 4.97 & 0.072 \\
\hline Deboned breast & $570.0 a$ & 505.0ab & $528.0 a b$ & $478.0 \mathrm{~b}$ & 8.46 & 0.013 \\
\hline Drumstick and thigh & 0.638 & 0.613 & 0.606 & 0.603 & 6.37 & 0.422 \\
\hline Drumette and wing & 0.222 & 0.222 & 0.208 & 0.208 & 6.31 & 0.122 \\
\hline Breast Fillet** & 0.105 & 0.107 & 0.106 & 0.098 & 8.88 & 0.321 \\
\hline Gizzard & 0.036 & 0.039 & 0.032 & 0.035 & 13.29 & 0.113 \\
\hline Liver & 0.051 & 0.048 & 0.048 & 0.044 & 9.11 & 0.074 \\
\hline Heart & 0.013 & 0.011 & 0.012 & 0.013 & 13.74 & 0.143 \\
\hline \multicolumn{7}{|c|}{ Carcass yield - Relative weight(\%) } \\
\hline C-FHN & 71.44 & 71.44 & 72.10 & 70.11 & 2.34 & 0.244 \\
\hline Breast with bone* & 36.06 & 36.99 & 37.72 & 36.50 & 4.96 & 0.455 \\
\hline Deboned breast & 27.76 & 25.54 & 26.40 & 25.04 & 8.93 & 0.229 \\
\hline Drumstick and thigh & 31.01 & 30.83 & 30.26 & 31.60 & 4.63 & 0.453 \\
\hline Drumette and wing & 10.83 & 11.18 & 10.41 & 10.91 & 4.49 & 0.081 \\
\hline Breast fillet** & 18.75 & 21.38 & 20.20 & 20.54 & 10.27 & 0.203 \\
\hline
\end{tabular}

Lowercase letters on the lines differ from each other, according to the Tukey test $(p<0.05)$.

LW (live weight); C-FHN (carcass without feet, head and neck). *Pectoralis majorandPectoralis minormuscles. ** Pectoralis minormuscle.

fibers composing the different commercial parts. Moreover, the respiratory rate of broilers increases during cyclic heat stress, as reported by Marchini et al. (2007), leading to greater breast muscle fiber activity (Faria Filho et al., 2006) and glycogen depletion, which is the main energy source of muscles (Geraert et al., 1996; Akşit et al., 2006). This may also explain the lower absolute breast weight observed in the broilers submitted for cyclic heat stress for a longer age period.

The current results are consistent with reports of Plavnik \& Yahav (1998), who subjected male broilers to cyclic heat stress $\left(35^{\circ} \mathrm{C}\right.$, from 07:00 to 17:00 between 4 and 8 weeks of age) and recorded an $8 \%$ breast weight reduction in comparison with birds kept under thermal comfort condition $\left(25^{\circ} \mathrm{C}\right)$. Salabi et al. (2011) also did not find any differences in liver weight and thigh yield between broilers exposed to heat stress (37 ${ }^{\circ} \mathrm{C}$ for 6 hours at 45\% RH) between 3 and 7 weeks of age and those kept in thermoneutral environments.

The obtain giblet results are different from those reported by Oliveira et al. (2006a), who found a decrease in absolute and relative gizzard, heart and liver weights in broiler kept in a climatic chamber under chronic heat stress $\left(32^{\circ} \mathrm{C}\right)$ for 24 hours between 22 and 42 days of age.

The comparison among studies on the effects of heat stress on broiler performance and carcass parameters is limited by the lack of an accurate index that effectively describes heat stress degrees to which birds are subjected under experimental conditions. In addition, most studies do not differentiate shortfrom long-term responses to hyperthermia (GonzalezEsquerra \& Leeson, 2006).

Different physiological responses developed by broilers subjected to heat stress may negatively influence their productive performance. These responses depend on the duration of heat-stress exposure and the age at which birds experienced the stress stimulus. According to Rosa et al. (2007), the age at which the heat stress is applied to the animals plays an important role in their responses to stress.

\section{CONCLUSION}

The cyclic heat stress applied to male broilers for one hour did not impair their performance, regardless of the age periods of exposure; however, breast weight was reduced when it was applied between 16 and 42 days of age.

\section{REFERENCES}

Abu-Dieyeh ZHM. Effect of high temperature per se on growth performance of broilers. International Journal of Poultry Science 2006;5(1):19-21.

Akşit M, Yalçin S, Özkan S, Metin K, Özdemir D. Effects of temperature during rearing and crating on stress parameters and meat quality of broilers. Poultry Science 2006;85(11):1867-1874. 
Marchini CFP, Fernandes EA,

Nascimento MRBM, Araújo EG,

Guimarães EC, Bueno JPR,

Fagundes NS, Café MB

\section{The Effect of Cyclic Heat Stress Applied to Different Broiler Chicken Brooding Stages on Animal Performance and Carcass Yield}

Al-Fataftah AA, Abu-Dieyeh ZHM. Effect of chronic heat stress on broiler performance in Jordan. International Journal of Poultry Science 2007;6(1):64-70

Altan Ö, Altan A, Oguz I, Pabuçcuoglu A, Konyalioglu S. Effects of heat stress on growth, some blood variables and lipid oxidation in broilers exposed to high temperature at an early age. British Poultry Science 2000;41(3):489-493

Baldwin RL, Smith NE, Taylor J, Sharp M. Manipulating metabolic parameters to improve growth rate and milk secretion. Journal of Animal Science 1980;51(6):1416-1428.

Banks WJ. Histologia veterinária aplicada. 2 ed. São Paulo: Manole; 1992.

Borges SA, Maiorka A, Fischer da Silva AV. Fisiologia do estresse calórico e a utilização de eletrólitos em frangos de corte. Ciência Rural 2003;33(5):975-981

Cobb. Handbook de manejo de frangos de corte. 2008. Available from: http://wp.ufpel.edu.br/avicultura/files/2012/04/Cobb-HandbookFrango-Corte-BR.pdf

Dionello NJL, Macari M, Ferro JA, Rutz F, Ferro MIT, Furlan RL. Respostas fisiológicas associadas à termotolerância em pintos de corte de duas linhagens por exposição a altas temperaturas. Revista Brasileira de Zootecnia 2002;31(1):79-85.

Donald JPE. El abc de la ventilación en galpones avícolas. Avicultura Profesional 1997;15(4):24-28.

Faria Filho DE, Rosa PS, Figueiredo DF, Dahlke F, Macari M, Furlan RL. Low-protein diets on broilers performance reared under different temperatures. Pesquisa Agropecuária Brasileira 2006;41(1):101-106.

Fernandes LM, Vieira SL, Baptista CB. Desenvolvimento de órgãos da digestão e rendimento de carcaça de frangos de corte de diversas origens genéticas criados com bebedouros pendular e nipple. Revista Brasileira de Ciência Avícola 2002;4(1):1-12.

Ferreira, DF. Análises estatísticas por meio do Sisvar para Windows versão 4.6. Anais da $45^{a}$ Reunião Anual da Região Brasileira da Sociedade Internacional de Biometria; 2000; São Carlos, São Paulo. Brasil. p.255258.

Furlan RL, Carvalho NC, Malheiros EB, Macari M. Efeito da restrição alimentar inicial e da temperatura ambiente sobre o desenvolvimento de vísceras e ganho compensatório em frangos de corte. Arquivo Brasileiro de Medicina Veterinária e Zootecnia 2001;53(4):1-7.

Geraert PA, Padilha JCF, Guillaumin S. Metabolic and endocrine changes induced by chronic heat exposure in broiler chickens: growth performance, body composition and energy retention. British Journal of Nutrition 1996;75(2):195-204.

Gonzalez-Esquerra R, Leeson S. Physiological and metabolic responses of broilers to heat stress - implications for protein and amino acid nutrition. World's Poultry Science Journal 2006;62(2):282-295.

Hurwitz S, Weiselberg M, Eisner U, Bartov I, Riesenfeld G, Sharvit M, et al. The energy requirements and performance of growing chickens and turkeys as affected by environmental temperature. Poultry Science 1980;59(10):2290-2299.

Lara LJC, Baião NC. Estresse calórico em aves. In: Pereira JCC, editor. Fundamentos de bioclimatologia aplicados à produção animal. Belo Horizonte: FEPMVZ; 2005. p.165-180.

Leone ER, Bernal FEM, Furlan RL, Malheiros EB, Macari M. Efeitos da restrição alimentar proteica ou energética sobre o crescimento de frangos de corte criados em diferentes temperaturas ambiente. Revista Brasileira de Zootecnia 1997;30(3 Suppl 1):1058-1064.
Lin H, Du R, Gu X, Zhang Z. The effect of thermal environment on growth of neonatal chicks: I. The development of thermoregulation. Journal of Animal Physiology and Animal Nutrition 1996;75(4-5):200-206.

Marchini CFP, Silva PL, Nascimento MRBM, Tavares M. Frequência respiratória e temperatura cloacal em frangos de corte submetidos à temperatura ambiente cíclica elevada. Archives of Veterinary Science 2007;12(1):41-46

May JD, Lott BD. The effect of environmental temperature on growth and feed conversion of broilers to 21 days of age. Poultry Science 2000;79(5):669-671.

Mazzi CM, Ferro MIT, Coelho AAD, Savino VJM, Macari M, Ferro JA, et al. Effect of heat exposure on the thermoregulatory responses of selected naked neck chickens Arquivo Brasileiro de MedicinaVeterinária e Zootecnia2 002;54(1):35-41.

Mello JLM, Boiago MM, Giampietro-Ganeco A, Berton MP, Vieira LDC, Souza RA, et al. Periods of heat stress during the growing affects negatively the performance and carcass yield of broilers. Archivos de Zootecnia 2015:64(248):339-345

Oliveira GA, Oliveira RFM, Donzele JL, Cecon PR, Vaz RGMV, Orlando UAD. Efeito da temperatura ambiente sobre o desempenho e as características de carcaça de frangos de corte dos 22 aos 42 dias. Revista Brasileira de Zootecnia 2006a;35(4):1398-1405.

Oliveira Neto AR, Oliveira RFM, Donzele JL, Rostagno HS, Ferreira RA, Maximiano $\mathrm{HC}$, et al. Efeito da temperatura ambiente sobre o desempenho e características de carcaça de frangos de corte alimentados com dieta controlada e dois níveis de energia metabolizável. Revista Brasileira de Zootecnia 2000;29(1):183-190.

Oliveira RFM, Donzele JL, Abreu MLT, Ferreira RA, Vaz RGMV, Cella PS Efeitos da temperatura e da umidade relativa sobre o desempenho e o rendimento de cortes nobres de frangos de corte de 1 a 49 dias de idade. Revista Brasileira de Zootecnia 2006b:35(3):797-803.

Ono $\mathrm{Y}$, Iwamoto $\mathrm{H}$, Takahara $\mathrm{H}$. The relationship between muscle growth and the growth of different fiber types in the chicken. Poultry Science 1993;72(3):568-576

Plavnik I, Yahav S. Effect of environmental temperature on broiler chickens subjected to growth restriction at an early age. Poultry Science 1998;77(6):870-872

Quinteiro-Filho WM, Ribeiro A, Ferraz-De-Paula V, Pinheiro ML, Sakai M, Sá LRM, et al. Heat stress impairs performance parameters, induces intestinal injury, and decreases macrophage activity in broiler chickens. Poultry Science 2010;89(9):1905-1914.

Quinteiro-Filho WM, Rodrigues MV, Ribeiro A, Ferraz de Paula V, Pinheiro $\mathrm{ML}$, Sa LRM, et al. Acute heat stress impairs performance parameters and induces mild intestinal enteritis in broiler chickens: role of acute HPA axis activation. Journal of Animal Science 2012;90(6):1986-1994.

Ribeiro AML, Penz Jr. AM, Teeter RG. Effects of 2-Hydroxy-4-(methylthio) butanoic acid and dl-methionine on broiler performance and compensatory growth after exposure to two different environmental temperatures. Journal of Applied Poultry Research 2001;10(4):419442.

Rosa PS, Faria Filho DE, Dahlke F, Vieira BS, Macari M, Furlan RL. Performance and carcass characteristics of broiler chickens with different growth potential and submitted to heat stress. Revista Brasileira de Ciência Avícola 2007;9(3):181-186

Rosser BWC, Wick M, Waldbillig DM, Bandman E. Heterogeneity of myosin heavy-chain expression in fast-twitch types of mature avian pectoralis muscle. Biochemistry and Cell Biology 1996;74(4):715-728. 
Marchini CFP, Fernandes EA,

Nascimento MRBM, Araújo EG,

Guimarães EC, Bueno JPR,

Fagundes NS, Café MB

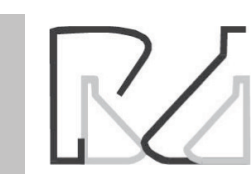

The Effect of Cyclic Heat Stress Applied to Different

Broiler Chicken Brooding Stages on Animal

Performance and Carcass Yield
Rostagno HS, Albino LFT, Donzele JL, Gomes PC, Oliveira RF, Lopes DC, et al. Tabelas brasileiras para aves e suínos: composição de alimentos e exigências nutricionais. 2.ed. Viçosa: Universidade Federal de Viçosa; 2005. Available from: https://www.agencia.cnptia.embrapa.br/ Repositorio/Tabelas+brasileiras+-+Rostagno_000gy1 tqvm602wx7ha0b 6gs0xfzo6pk5.pdf.

Sakomura NK, Rostagno HS. Métodos de pesquisa em nutrição de monogástricos. Jaboticabal: Funep; 2016.

Salabi F, Boujarpor M, Fayazi J, Salari S, Nazari M. Effects of different levels of zinc $n$ the performance and carcass characteristics of broiler reared under heat stress condition. Journal of Animal and Veterinary Advances 2011;10(10):1332-1335

Sartori JR, Gonzales E, Macari M, Dal Pai V, Oliveira HN. Tipos de fibras no músculo flexor longo do hálux de frangos de corte submetidos ao estresse pelo calor e frio e alimentados em "pair-feeding". Revista Brasileira de Zootecnia 2003;32(4):918-925.

Silva EC. Aspectos biomecânicos musculares relacionados à administração experimental de corticosteroide sistêmico [dissertation]. Ribeirão Preto (SP): Universidade de São Paulo; 2002. Available from: http://www. teses.usp.br/teses/disponiveis/82/82131/tde-01092003-105926/pt-br. php.
Silva MAN, Barbosa Filho JAD, Silva CJM, Silva IJO, Coelho AD, Savino, $J M$. Avaliação do estresse térmico em condição simulada de transporte de frangos de corte. Revista Brasileira de Zootecnia 2007;36(4 Suppl):1126-1130.

Silva RBC, Costa ACL. Variações termo-higrométricas horárias em ecossistema de manguezal durante época seca na região Bragantina, no Estado do Pará. Anais do $11^{\circ}$ Congresso Brasileiro de Meteorologia; 2000; Rio de Janeiro, Rio de Janeiro. Brasil. p.2300-2303 [cited 2016 Ago 03]. Available from: http://www.cbmet.com/cbm-files/12-d32c6e a7cd5100520b592d36d238ecb0.pdf.

Yahav S, Straschnow A, Luger D, Shinder D, Tanny J, Cohen S. Ventilation, sensible heat loss, broiler energy, and water balance under harsh environmental conditions. Poultry Science 2004;83(4):253-258.

Yanagi Jr ET, Xin H, Gates RS. Modelling partial surface evaporative cooling of chickens. Proceedings of the ASAE Annual International; 2001; St Joseph, Sacramento. California. St Joseph: ASAE; 2001 [paper 01-3011]. Available from: http://lib.dr.iastate.edu/cgi/viewcontent. cgi? article=1185\&context=abe_eng_conf.

Zhang ZY, Jia GQ, Zuo JJ, Zhang Y, Lei J, Ren L, et al. Effects of constant and cyclic heat stress on muscle metabolism and meat quality of broilers breast fillet and thigh meat. Poultry Science 2012;91(11):2931-2937. 